\title{
Economic assessment of WECS for water pumping systems in the North Region of Cameroon
}

\author{
Dieudonné Kaoga Kidmo ${ }^{1, *}$, Bachirou Bogno ${ }^{2,3}$, Kodji Deli ${ }^{1}$, Michel Aillerie ${ }^{3}$, Bello Pierre Ngoussandou $^{1}$ \\ ${ }^{1}$ Department of Renewable Energy, National Advanced School of Engineering of Maroua, University of Maroua, P.O. Box 46 \\ Maroua, Cameroon \\ ${ }^{2}$ Department of Physics, Higher Teachers' Training College, University of Maroua, P.O. Box 46 Maroua, Cameroon \\ ${ }^{3}$ Laboratoire Matériaux Optiques, Photonique et Systèmes, LMOPS, EA 4423, Université de Lorraine, Metz, 57070, France
}

Received: 20 December 2020 / Received in final form: 15 March 2021 / Accepted: 16 March 2021

\begin{abstract}
This paper analyses the potential utilization of wind electric pumping for water distribution in offgrid locations of the North Region of Cameroon (NRoC), using ground measured data as well as long-term satellite-derived data. Furthermore, this paper puts emphasis on statistical indexes of accuracy for the comparison of measured (2007-2012) and long-term satellite-derived (2005-2020) data. The outcome of this study clearly indicates that long-term satellite-derived data, obtained through the Prediction of Worldwide Renewable Energy Resources, can be considered as a viable alternative to missing site-specific data from ground stations, mainly in developing countries. The accuracy of satellite-based wind resource is deemed sufficient to provide a reasonable assessment in the initial phase of wind project planning, before in situ measurements with high accuracy are available. To model wind speeds characteristics, the energy pattern factor method (EPF) has been utilized as one of the reliable Weibull distribution methods for the assessment of wind energy potential at desired turbines heights in the selected locations. Five 20-kW pitch-controlled wind turbines (WT) with a hub height of $30 \mathrm{~m}$, are considered to evaluate the power output and energy produced. Volumetric flow rates and costs of water produced are estimated. The results showed that, out of the eight chosen locations, Figuil shows the best combination of capacity factors $(\mathrm{CF})$ and costs of energy (COE), while the site of Poli displays the worst values of $\mathrm{CF}$ and $\mathrm{COE}$, no matter which of the five WT is employed. Thus, selecting WT for low wind speeds regimes, should require to combine location wind resource and WT characteristics such as lower cut-in wind speed $(1.5 \mathrm{~m} / \mathrm{s})$ as well as lower rated wind speed $(8.0 \mathrm{~m} / \mathrm{s})$ in order to successfully and affordably implement the wind technology in the NRoC.
\end{abstract}

\section{Introduction}

The sustainable development of a country is closely linked to the utilization of renewable energy resources (RES) at its disposal [1]. RES provide not only an important source of employment, wealth and profits to the country, but also play a critical role in building a sustainable and modern society [2-4]. Cameroon is endowed with conventional sources of energy such as natural gas and oil fuels, however associated with the emissions of both air pollutants, greenhouse gases and global warming. These conventional sources of energy share the fuel sources for electrical energy

\footnotetext{
* e-mail: kidmokaoga@gmail.com
}

production (natural gas and oil fuels) in the country and other energy needs of industries and populace [5]. Moreover, fossil fuel sources, which are gradually depleting, need to be preserved and utilized efficiently [6]. As the global energy demand increases and fossil fuels become a gradually expensive commodity to humankind, the focus has been shifted towards renewable energy for a sustainable development [7].

RES, such as biomass, geothermal, hydro, solar, wind are inexhaustible, clean, free and offer many benefits such as non-polluting and almost inexhaustible characteristics in contrast to fossil fuel [8]. To further add to RES advantages, they can be harnessed on a local basis for applications, such as decentralized production of electricity in remote or rural areas, with low density of population [9]. 
Amongst RES, wind energy is one of the world's most abundant and permanent energy source, with a high-level of utilization. In addition, the potential of wind energy is credited, in the best of cases, with forty times the global electricity demand [10]. Over the last twenty years, the yearly growth rate of global wind energy has achieved an average growth rate of $22 \%$ [11]. Wind energy conversion systems (WECS) are considered as a mature and costcompetitive technology for electricity production [12], which is produced locally [13], but its dissemination remains marginal in most African countries. WECS necessitate to correctly characterize the wind resource over a location in addition to its geographic distribution [14]. As result, wind power is poised to play a key role in meeting global growing demand for electricity, especially in developing countries such as Cameroon, where it can be harnessed at an affordable cost on a local basis for water pumping applications.

The NRoC lays in a low wind speed regime and as a result the region is faced with numerous challenges in developing wind energy [15]. Measured wind data are mostly available at the ground measurements station at the Garoua main airport, while for the seven other considered sites located beyond a radius of at least $50 \mathrm{~km}$ of the main measuring wind station, there are no ground measurements stations. Therefore, long-term satellitederived data [16], obtained through the POWER (Prediction of Worldwide Renewable Energy Resources), are deemed suitable and a viable alternative to missing site-specific data from ground stations [17-19]. These satellite-derived data are at daily level, at a $0.5 \times 0.5-$ degree resolution. Additional scientific literature related to the use of long-term satellite-derived data and their accuracy in comparison with in situ measurements are provided as referenced [20-23].

The aim of this paper is to acknowledge the use of satellite-based wind resource as appropriate data to provide a reasonable assessment, before higher-accuracy in situ measurements are accessible. Furthermore, this work explores wind power production using electric systems for water pumping in the NRoC. Measured wind speeds at $10 \mathrm{~m}$ height above ground level (agl), in hourly time-series format, from January 2007 to January 2012 were collected through a cup-generator anemometer for Garoua. When measured ground level data remained nonexistent, satellite-derived data for the sites of Bashéo, Beka, Figuil, Pitoa, Poli, Rey-Bouba and Touboro, were obtained from the NASA Langley Research Center (LaRC) POWER Project funded through the NASA Earth Science/Applied Science Program [24]. The accuracy of satellite-derived data for Garoua (the only site with ground measurements) was assessed using statistical indexes of accuracy, namely coefficient of determination $\left(\mathrm{R}^{2}\right)$, index of agreement (IOA), mean bias error (MBE), root mean square error (RMSE) and relative root mean square error (RRMSE).

Kidmo et al. [5] summarized most recent studies performed across Cameroon to investigate wind speeds and power characteristics, wind energy and costs of WECS. Recent and relevant research studies related to Garoua are detailed as followed. Kidmo et al. [25] performed a statistical analysis of wind speed distribution using six Weibull Methods for wind power assessment. Kidmo et al. [26] evaluated wind energy potential for small scale water pumping. Less attention was so far paid to the combination of location wind resource and wind turbines (WT) characteristics such as cut-in wind speed as well as rated wind speed. This paper highlights the use of low wind speeds WT to take full advantages of local wind resource and WT characteristics. Capacity factors $(\mathrm{CF})$, costs of energy generated $(\mathrm{XAF} / \mathrm{kWh})$ and water produced $(\mathrm{XAF} /$ $\mathrm{m}^{3}$ ) are estimated using the Present Value Cost (PVC) method of energy produced per year, considering the frequency at which WT produce power.

To model wind speeds characteristics, the energy pattern factor method (EPF) $[27,28]$ has been utilized as one of the reliable Weibull distribution methods for the assessment of wind energy potential at desired turbines heights in the selected locations. Five $20-\mathrm{kW}$ pitchcontrolled WT with a hub height of $30 \mathrm{~m}$, are considered to evaluate the power output and energy produced. Volumetric flow rates and costs of water produced are estimated using a $50 \mathrm{~m}$ pumping head, for the sake of simplicity. The results showed that, out of the eight chosen locations, Figuil shows the best combination of capacity factors $(\mathrm{CF})$ and costs of energy $(\mathrm{COE})$, while the site of Poli displays the worst values of $\mathrm{CF}$ and $\mathrm{COE}$, no matter which of the five WT is employed. Thus, selecting WECS for low wind speeds regimes, should require to combine location wind resource and WT characteristics such as lower cut-in wind speed $(1.5 \mathrm{~m} / \mathrm{s})$ as well as lower rated wind speed $(8.0 \mathrm{~m} / \mathrm{s})$ in order to successfully and affordably implement the wind technology in the NRoC.

\section{Methodology}

\subsection{Study area}

The North Region as shown in Figure 1, is one of the ten regions of Cameroon, Located between $7.30-10.00 \mathrm{~N}$ latitude and $12.30-15.00 \mathrm{E}$ longitude. It covers an area of $66090 \mathrm{~km}^{2}$ and is bordered by two regions of the country, the Far North Region to the north and the Adamawa Region to the south, Chad to the east, Central African Republic to the southeast and Nigeria to the west. The North region accounts for one of the driest regions of Cameroon under the influence of the harmattan winds in the dry season which lasts eight months, temperatures rise at their highest $\left(40-45^{\circ} \mathrm{C}\right)$ and there is no rainfall. During the rainy season which lasts four months, average rainfall is between 900 and $1500 \mathrm{~mm}$ and torrential rains are observed as well as lower temperatures compared to dry season. The Benoue depression constitutes the primary land feature of the North region, with an elevation in the range of zero to $200 \mathrm{~m}$. Land elevations are in the range of $200-500$ and $500-1000 \mathrm{~m}$, respectively in the north and south of the region [29]. The selected sites, namely, Bashéo, Beka, Figuil, Garoua, Pitoa, Poli, Rey-Bouba and Touboro, as 


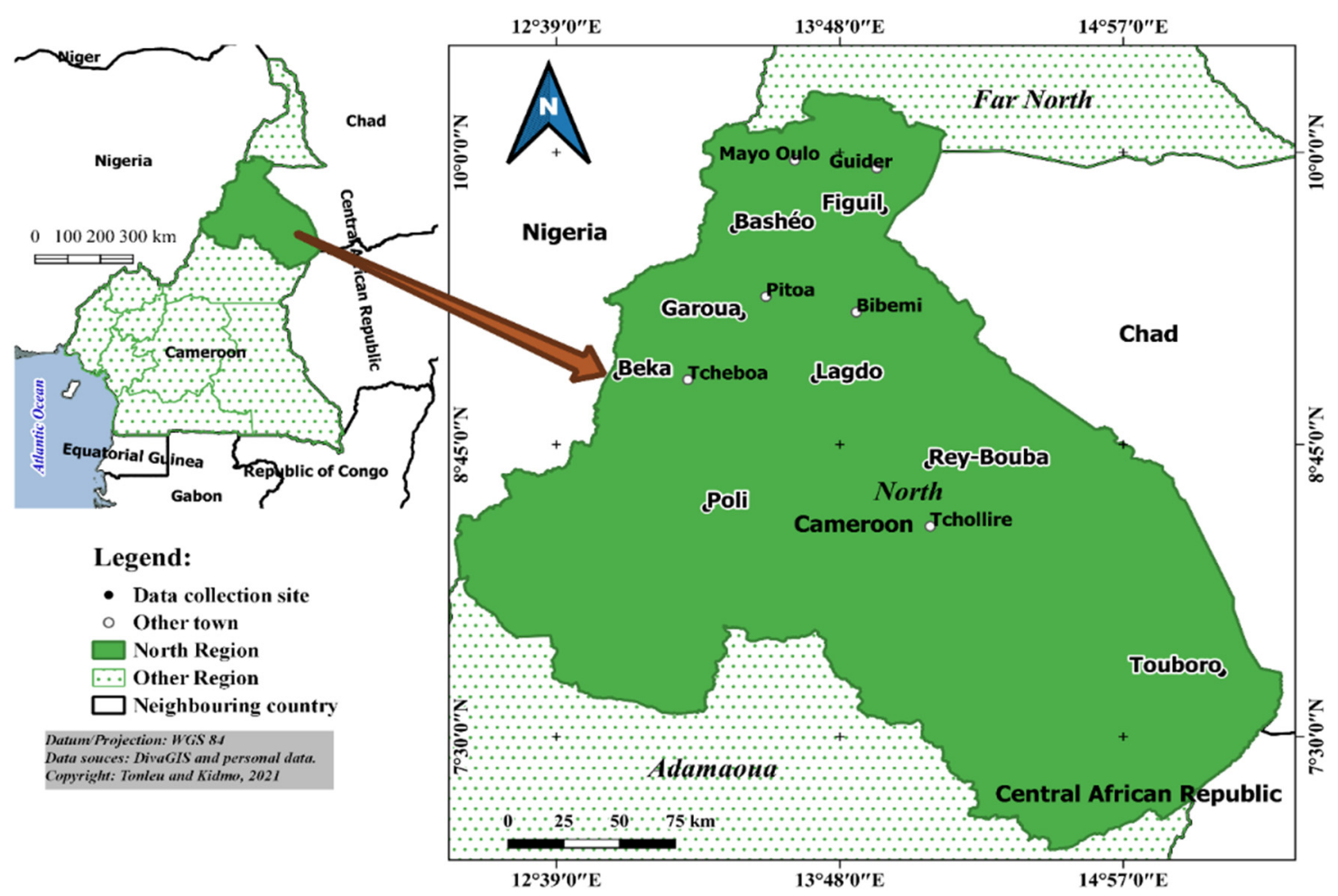

Fig. 1. Map showing the eight selected sites of the North Region of Cameroon.

shown in Figure 1, have been chosen based on relevant landscape information they provide in order to fully assess the potential of wind energy in the NRoC.

\subsection{Wind data description and source}

Two sources of data have been utilized in this work, measurements from a ground station for the site of Garoua and long-term satellite-derived data for the seven other sites. Wind speed measurements for the locality of Garoua, at $10 \mathrm{~m}$ height agl, in hourly time-series format, from January 2007 to January 2012 have been collected through a cup-generator anemometer at the Garoua, main meteorological station [25]. For the seven other selected sites of the north region, measured ground level data are non-existent. Therefore, long-term daily satellite-derived data, from January 2005 to January 2020, obtained through the POWER, have been utilized. These data were obtained from the NASA Langley Research Center (LaRC) POWER Project funded through the NASA Earth Science/Applied Science Program [24]. Table 1 provides geographical coordinates of the eight sites, as well as mean ambient temperature and measurement period.

\subsection{Mean wind speed and standard deviation}

Monthly mean wind speed $v_{m}$ and standard deviation $\sigma$ of wind speed data are calculated as Equations (1) and (2) [25]:

$$
v_{m}=\frac{1}{N}\left(\sum_{i=1}^{N} v_{i}\right)
$$

$$
\sigma=\left[\frac{1}{N-1} \sum_{i=1}^{n}\left(v_{i}-v_{m}\right)^{2}\right]^{1 / 2}
$$

Where:

$$
\begin{aligned}
& v_{m}=\text { mean wind speed }[\mathrm{m} / \mathrm{s}] \\
& \sigma=\text { standard deviation of the mean wind speed }[\mathrm{m} / \mathrm{s}] \\
& v_{i}=\text { wind speed }[\mathrm{m} / \mathrm{s}] \\
& N=\text { number of wind speed data. }
\end{aligned}
$$

After the statistical analysis of wind data, monthly mean wind speeds and standard deviations for Garoua using measured and satellite-derived data, are summarized in Table 2, while Figures 2 and 3 show, respectively monthly mean wind speeds and standard deviations using satellite-derived data for for Bashéo, Beka, Figuil, Garoua, Pitoa, Poli, Rey-Bouba and Touboro. The magnitude of monthly mean measured wind speeds and standard deviations for Garoua at $10 \mathrm{~m}$ height agl, lay respectively within the range of 1.24 to $2.71 \mathrm{~m} / \mathrm{s}$ and 0.73 to $1.39 \mathrm{~m} / \mathrm{s}$, while corresponding values using satellite-derived data range from 1.67 to $3.38 \mathrm{~m} / \mathrm{s}$ and from 0.47 to $1.00 \mathrm{~m} / \mathrm{s}$, in that order.

\subsection{Weibull probability density function}

The Weibull probability density function (PDF), which is a special case of a generalized two-parameter Gamma distribution, has been extensively utilized in scientific literature for wind speed forecasting and wind energy potential assessment [30-32]. Weibull PDF can be characterized by its PDF $f(V)$ using Equation (3) and cumulative distribution function (CDF), $F(V)$ using 
Table 1. Geographical data for eight selected sites of the North Region.

\begin{tabular}{|c|c|c|c|c|c|c|}
\hline Location & $\begin{array}{l}\text { Latitude } \\
\left({ }^{\circ}\right)\end{array}$ & $\begin{array}{l}\text { Longitude } \\
\left({ }^{\circ}\right)\end{array}$ & $\begin{array}{l}\text { Elevation } \\
(\mathrm{m})\end{array}$ & $\begin{array}{l}\text { Ambient } \\
\text { temperature } \\
\left({ }^{\circ} \mathrm{C}\right)\end{array}$ & $\begin{array}{l}\text { Satellite } \\
\text { Measurement } \\
\text { period }\end{array}$ & $\begin{array}{l}\text { In situ } \\
\text { Measurement } \\
\text { period }\end{array}$ \\
\hline Bashéo & 9.6721 & 13.3711 & 403.8 & 27.47 & Jan 2005-Jan 2020 & \\
\hline Beka & 9.0437 & 12.8982 & 296.16 & 27.90 & Jan 2005-Jan 2020 & \\
\hline Figuil & 9.7524 & 13.976 & 407.05 & 27.67 & Jan 2005-Jan 2020 & \\
\hline Garoua & 9.2955 & 13.3998 & 291.79 & 28.19 & Jan 2005-Jan 2020 & Jan 2007-Jan 2012 \\
\hline Lagdo & 9.2862 & 13.3766 & 291.79 & 28.19 & Jan 2005-Jan 2020 & \\
\hline Poli & 8.4785 & 13.2595 & 512.62 & 26.67 & Jan 2005-Jan 2020 & \\
\hline Rey-Bouba & 8.6633 & 14.1595 & 344.08 & 28.17 & Jan 2005-Jan 2020 & \\
\hline Touboro & 7.7739 & 15.3489 & 651.63 & 25.96 & Jan 2005-Jan 2020 & \\
\hline
\end{tabular}

Table 2. Monthly mean wind speeds and standard deviations for Garoua using measured and satellite-derived data.

\begin{tabular}{llllll}
\hline Period & \multicolumn{2}{l}{ Measured } & & \multicolumn{2}{c}{ Satellite-derived } \\
\cline { 2 - 3 } & $\boldsymbol{v}_{\mathrm{mG}}$ & $\sigma_{\boldsymbol{G}}$ & & $\boldsymbol{v}_{\mathrm{mS}}$ & $\sigma_{\boldsymbol{S}}$ \\
\hline Jan & 1.585 & 0.920 & & 3.21 & 0.84 \\
Feb & 1.588 & 0.930 & & 3.38 & 0.95 \\
Mar & 2.093 & 1.057 & & 3.35 & 1.00 \\
Apr & 2.711 & 1.385 & & 3.09 & 0.92 \\
May & 2.511 & 1.256 & 2.54 & 0.69 \\
Jun & 2.492 & 1.296 & & 2.31 & 0.74 \\
Jul & 2.333 & 1.287 & 2.22 & 0.66 \\
Aug & 1.840 & 1.017 & & 2.04 & 0.63 \\
Sep & 1.603 & 0.884 & & 1.67 & 0.47 \\
Oct & 1.583 & 0.949 & & 1.70 & 0.49 \\
Nov & 1.395 & 0.870 & & 2.21 & 0.64 \\
Dec & 1.237 & 0.733 & 2.88 & 0.70 \\
Whole Year & 1.915 & 1.168 & 2.55 & 0.68 \\
\hline
\end{tabular}

Equation (4) [33]:

$$
\begin{gathered}
f(v)=\left(\frac{k}{C}\right) \cdot\left(\frac{v}{C}\right)^{k-1} \cdot \exp \left[-\left(\frac{v}{C}\right)^{k}\right] \\
F(v)=1-\exp \left[-\left(\frac{v}{C}\right)^{k}\right]
\end{gathered}
$$

Where:

$$
\begin{aligned}
& f(v)=\text { probability of observing wind speed } v ; \\
& v=\text { wind speed }[\mathrm{m} / \mathrm{s}] \\
& C=\text { Weibull scale parameter }[\mathrm{m} / \mathrm{s}] \\
& k=\text { Weibull shape parameter. }
\end{aligned}
$$

Weibull parameters $\mathrm{k}$ and $\mathrm{C}$ are typically obtained using well-established estimation methods $[25,34]$. In this paper, Weibull parameters are computed using the energy pattern factor method (EPF). The first step is to define the power density expressed using Equation (5) [35].

$$
P_{d}=\frac{1}{2} \rho\left(\frac{v}{C}\right) \int_{0}^{\infty} v^{3} f(v) d v
$$

Where:

$$
\rho=\text { air density at the site; }
$$

The air density (in kilograms per cubic meter) at a given location is calculated as the mass of a quantity of air (in $\mathrm{kg}$ ) divided by its volume (in cubic meter). It depends on elevation and temperature above sea level and can be computed [36] using Equation (6).

$$
\rho_{a}=\frac{353.049}{T} e^{\left(-0.034 \frac{Z}{T}\right)}
$$

Where:

$Z=$ elevation $(\mathrm{m})$;

$T=$ temperature at the considered site $\left({ }^{\circ} \mathrm{K}\right)$.

The second step of the EPF method is to determine the energy pattern factor $\left(E_{p f}\right)$, as Equation (7) [37]:

$$
E_{p f}=\frac{\left(v^{3}\right)_{m}}{\left(v_{m}\right)^{3}}=\frac{\left(\frac{1}{n} \sum_{i=1}^{n} v_{i}{ }^{3}\right)}{\left(\frac{1}{n} \sum_{i=1}^{n} v_{i}\right)^{3}}
$$

Where:

$v_{m}=$ mean wind speed $[\mathrm{m} / \mathrm{s}] ;$

$\left(v^{3}\right)_{m}=$ mean of wind speed cubes.

Once the energy pattern factor is calculated by using Equation (7), the Weibull shape parameter is estimated from Equation (8) [38]:

$$
k=1+\frac{3.69}{\left(E_{p f}\right)^{2}}
$$

where $\mathrm{k}$ is the dimensionless shape parameter illustrating how peaked the wind distribution is, while the scale parameter $\mathrm{C}$ indicates how 'windy' the wind location under consideration is [39].

The scale parameter is obtained using Equation (9):

$$
C=\frac{v_{m}}{\Gamma\left(1+\frac{1}{k}\right)}
$$




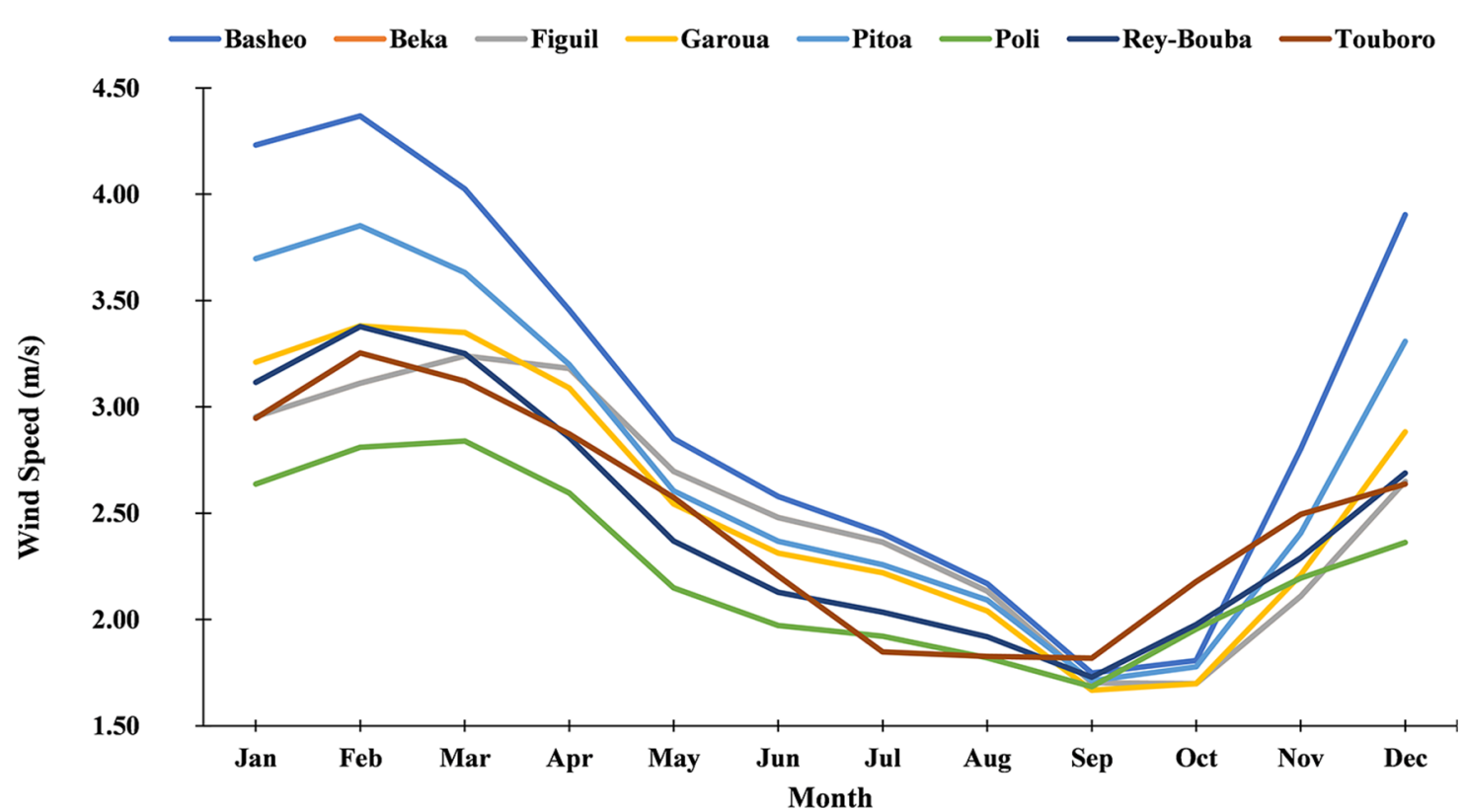

Fig. 2. Monthly mean wind speeds using satellite-derived data for Bashéo, Beka, Figuil, Garoua, Pitoa, Poli, Rey-Bouba and Touboro.

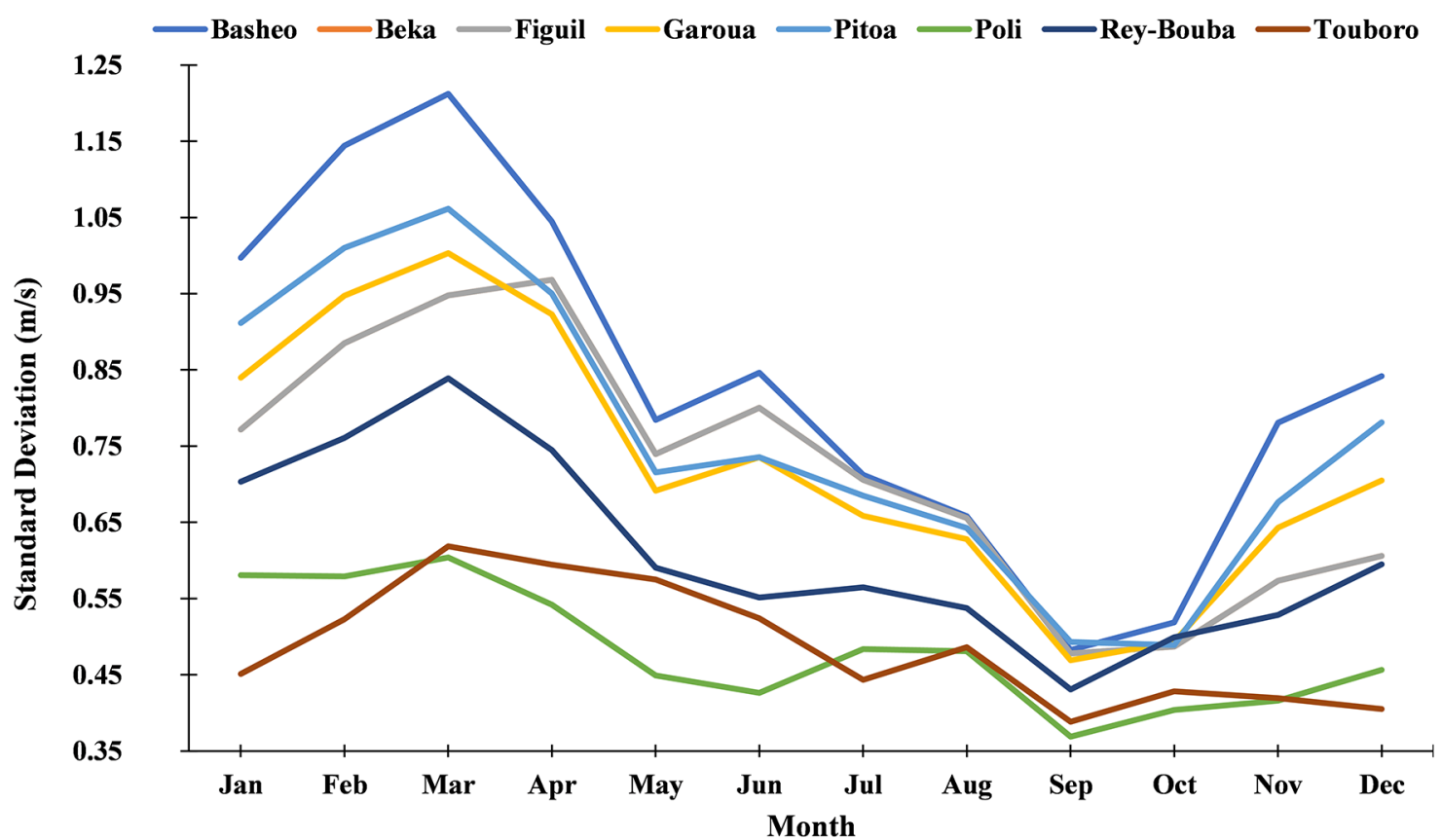

Fig. 3. Monthly standard deviations using satellite-derived data for Bashéo, Beka, Figuil, Garoua, Pitoa, Poli, Rey-Bouba and Touboro.

Where the standard gamma function is given by [40]:

$$
\Gamma(x)=\int_{0}^{\infty} t^{x-1} \exp (-t) d t
$$

The gamma function can be approximated by $[25,41]$ :

$$
\begin{aligned}
\Gamma(x)= & (\sqrt{2 \pi x})\left(x^{x-1}\right)\left(e^{-x}\right) \\
& \times\left(1+\frac{1}{12} x+\frac{1}{288} x^{2}-\frac{139}{51840} x^{3}+\ldots\right)
\end{aligned}
$$

\subsection{Statistical indexes of accuracy}

In order to evaluate the performance of the considered satellite-derived data of Garoua, the following statistical indexes of accuracy are utilized:

1. Mean Bias Error $(M B E)$ of satellite-derived values using Equation $(12)[42,43]$ :

$$
M B E=\left[\frac{1}{N} \sum_{i=1}^{N}\left(S a t_{i}-G r_{i}\right)^{2}\right]^{1 / 2}
$$


where $G r_{i}$ denotes cumulative frequency distribution (CFD) of measured values at wind speed $v_{i}$, in time step $i, S_{a t}$ the respective satellite-derived value, and $\mathrm{N}$ the number of non-zero wind speed data points. MBE provides basically the difference between CFD of average satellitederived and average measured values. Satellite-derived values are overestimated if $M B E>0$, while they are underestimated if $M B E<0$. $[44,45]:$

2. Root mean square error (RMSE) using Equation (13)

$$
R M S E=\left[\frac{1}{N} \sum_{i=1}^{N}\left(S a t_{i}-G r_{i}\right)^{2}\right]^{1 / 2}
$$

RMSE provides the deviation between satellite-derived and measured values. Successful forecasts correspond to low values of RMSE, while higher indicate deviations [43]. RMSE should be as close to zero as possible.

3. Relative root mean square error (RRMSE) using Equation (14) [30,46]:

$$
R R M S E=\frac{\left[\frac{1}{N} \sum_{i=1}^{N}\left(S a t_{i}-G r_{i}\right)^{2}\right]^{1 / 2}}{\frac{1}{N} \sum_{i=1}^{N} G r_{i}} \times 100
$$

RRMSE is calculated by dividing RMSE to the average of CFD of measured values. Ratings of satellite-derived values' accuracy can be defined as [47]:

Excellent:

Good:

Fair:

Poor: $[30,48]:$

4. Coefficient of determination $\left(\mathrm{R}^{2}\right)$ using Equation (15)

$$
R^{2}=1-\frac{\sum_{i=1}^{N}\left(G r_{i}-S a t_{i}\right)^{2}}{\sum_{i=1}^{N}\left(G r_{i}-\overline{S a t_{i}}\right)^{2}}
$$

$\mathrm{R}^{2}$ determines the linear relationship between CFD of average satellite-derived and average measured values. A higher $\mathrm{R}^{2}$ represents a better fit using satellite-derived data and the highest value it can get is 1 .

Where: $G r_{i}$ is the $i^{\text {th }}$ CFD of ground (measured) wind speeds, $S a t_{i}$ is the $i^{\text {th }}$ CFD of satellite-derived wind speeds, $\overline{S a t_{i}}$ is the mean value of $S a t_{i}, \mathrm{~N}$ the number of non-zero wind speed data points.

5. Index of Agreement (IOA) using Equation (16) $[30,49]$ :

$$
I O A=1-\frac{\overline{S a t_{i}}-\overline{G r_{i}}}{\sum_{i=1}^{N}\left(\left|S a t_{i}-\overline{G r_{i}}\right|+\left|G r_{i}-\overline{G r_{i}}\right|\right)^{2}}
$$

Where: $\bar{G} r_{i}$ denotes the average of $G r_{i}, \overline{S a t_{i}}$ is the mean value of $S a t_{i}, \mathrm{~N}$ the number of non-zero wind speed data points. IOA estimates the accuracy of satellite-derived wind speeds in predicting ground (measured) wind speeds. IOA values range from zero to one. IOA values above 0.5 imply efficiency in using satellite-derived data [43]

\subsection{Extrapolation of wind speeds at different hub heights}

In this study, five WT, using a $30 \mathrm{~m}$ hub height have been considered. Wind speeds data obtained at $10 \mathrm{~m}$ height agl, are therefore adjusted to the relevant WT hub height. The vertical extrapolation of scale and shape parameters at an elevation (z), is defined by the relationships in Equations (17) and (18) [50,51]:

$$
\begin{gathered}
C_{z}=C_{10} \times\left(\frac{z}{z_{10}}\right)^{n} \\
k_{z}=\frac{k_{10}}{1-0.00881 \ln (z / 10)}
\end{gathered}
$$

Where $z$ and $z_{10}$ are in meters and the power law exponent $n$ is given by Equation (19):

$$
n=\left[0.37-0.088 \ln \left(C_{10}\right)\right]
$$

Where, the scale $C_{10}$ and shape $k_{10}$ parameters are determined at $10 \mathrm{~m}$ height agl.

\subsection{Mean wind power density and energy density}

Wind power density $(P(v))$, in watts per square meter, is estimated using Equation (20) [52].

$$
P(v)=\frac{1}{2} \rho A v^{3}
$$

The mean wind power density $\left(p_{D}\right)$ based on the Weibull probability density function can be calculated using Equation (21) [33].

$$
p_{D}=\frac{P(v)}{A}=\frac{1}{2} \rho C^{3} \Gamma\left(1+\frac{3}{k}\right)
$$

The mean energy density $\left(E_{D}\right)$ over a period of time $\mathrm{T}$ is expressed as Equation (22).

$$
E_{D}=\frac{1}{2} \rho C^{3} \Gamma\left(1+\frac{3}{k}\right) T
$$

Where:

$\rho=$ air density at the site;

$A=$ swept area of the rotor blades $\left[\mathrm{m}^{2}\right]$.

\subsection{Wind turbine and electric pumping systems}

Five WT, from different manufacturers are considered, as illustrated by Table 3 . The five $\mathrm{WT}$ are represented by $\mathrm{WT}_{1}, \mathrm{WT}_{2}, \mathrm{WT}_{3}, \mathrm{WT}_{4}$, and $\mathrm{WT}_{5}$ to avoid using registered names, trademarks etc. These WT are designed for low 
Table 3. Characteristics of the selected wind turbines.

\begin{tabular}{llllll}
\hline Characteristics & $\mathrm{WT}_{1}$ & $\mathrm{WT}_{2}$ & $\mathrm{WT}_{3}$ & $\mathrm{WT}_{4}$ & $\mathrm{WT}_{5}$ \\
\hline Hub height $(\mathrm{m})$ & 30 & 30 & 30 & 30 & 30 \\
Rated power $\boldsymbol{P}_{\boldsymbol{R}}(\mathrm{kW})$ & 20 & 20 & 20 & 20 & 20 \\
Rotor diameter $(\mathbf{m})$ & 10 & 10 & 10 & 10 & 10 \\
Cut-in wind speed $\boldsymbol{V}_{\boldsymbol{C}}(\mathrm{m} / \mathrm{s})$ & 1.5 & 2.0 & 2.5 & 3.0 & 3.5 \\
Rated wind speed $\boldsymbol{V}_{\boldsymbol{R}}(\mathrm{m} / \mathrm{s})$ & 8 & 9 & 25 & 11 & 12 \\
Cut-off wind speed $\boldsymbol{V}_{\boldsymbol{F}}(\mathrm{m} / \mathrm{s})$ & 25 & 25 & 1,775 & 1,775 & 25 \\
Price $(\mathrm{USD} / \mathrm{kW})[53]$ & 1,775 & 1,775 & 1,065 & 1,065 & 1,775 \\
Price $(\mathrm{kXAF} / \mathrm{kW})$ & 1,065 & 1,065 & & & 1,065 \\
\hline
\end{tabular}

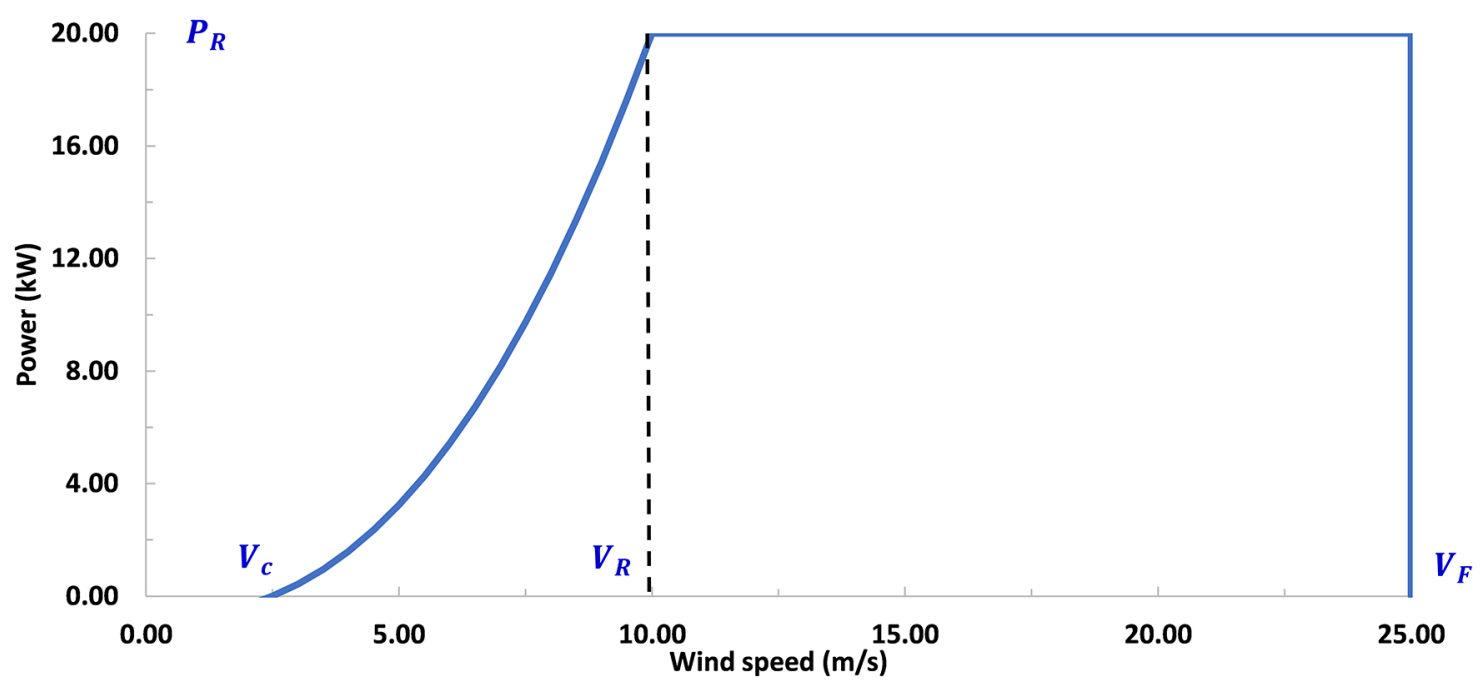

Fig. 4. Power Curve of a $20-\mathrm{kW}$ pitch-controlled WT, with technical specifications of $\mathrm{WT}_{3}$.

wind power density regime, for locations falling into Class 2 or lesser, based on PNL wind power classification scheme [50]. Although a $50 \mathrm{~m}$ pumping head is considered to calculate volumetric flow rates, a different pumping head can be considered, since the volumetric flow rate of water is inversely proportional to the pumping head.

\subsection{Power curve model and capacity factor}

The typical power curve of a $20-\mathrm{kW}$ pitch-controlled WT is shown in Figure 4. Four different zones are observed as illustrated. For WS in the range of zero to cut-in wind speed $\left(V_{C}\right)$, there is no output yielded. From the cut-in to rated WS $\left(V_{C}\right.$ to $\left.V_{R}\right)$, the power increases with the wind speed (WS). The power output curve is assumed to show a quadratic power shape, based on the selected power curve model in this work. From the rated WS $\left(V_{R}\right)$ to the cut-out WS $\left(V_{F}\right)$, the WT yields a constant output at the rated power $\left(P_{R}\right)$, regardless of WS variations. For WS higher than $V_{F}$, there is no output yielded.

\subsection{Power curve model and capacity factor}

The power curve model of a WT can be modelled by four parameters: the cut-in wind speed $\left(v_{c}\right)$, the rated wind speed $\left(v_{R}\right)$, the cut-off wind speed $\left(v_{F}\right)$ and the rated electrical power $\left(P_{e R}\right)$. In this study, the power output curve model of a WT can be approximated with the parabolic law, using the combination of Equation (23) [54]:

$$
P_{e}= \begin{cases}0 & \left(v<v_{c}\right) \\ P_{e R} \frac{v^{k}-v_{c}^{k}}{v_{R}{ }^{k}-v_{c}{ }^{k}} & v_{c} \leq v \leq v_{R} \\ P_{e R} & v_{R} \leq v \leq v_{F} \\ 0 & \left(v_{F}<v\right)\end{cases}
$$

The average power output $\left(P_{e, \text { ave }}\right)$ from the turbine, which is related to the total energy production can be determined from Weibull distribution as Equation (24):

$$
P_{e, a v e}=P_{e R}\left\{\frac{e^{-\left(\frac{v_{c}}{C}\right)^{k}-} e^{-\left(\frac{v_{R}}{C}\right)^{k}}}{\left(\frac{v_{R}}{C}\right)^{k}-\left(\frac{v_{c}}{C}\right)^{k}}-e^{-\left(\frac{v_{F}}{C}\right)^{k}}\right\}
$$

The capacity factor $\mathrm{CF}$ is defined as the ratio of the average power output $\left(P_{e, a v e}\right)$ to the rated electrical power $\left(P_{e R}\right)$ of the WT. The capacity factor $C F$ can thus be 
computed as Equation (25) [55]:

$$
C F=\left\{\frac{e^{-\left(\frac{v_{c}}{C}\right)^{k}-} e^{-\left(\frac{v_{R}}{C}\right)^{k}}}{\left(\frac{v_{R}}{C}\right)^{k}-\left(\frac{v_{c}}{C}\right)^{k}}-e^{-\left(\frac{v_{F}}{C}\right)^{k}}\right\}
$$

\subsection{Water pumping capacity}

The net hydraulic power output $\left(P_{\text {out }}\right)$ required to deliver a volume of water $V_{w}\left(m^{3}\right)$ can be expressed using Equation (26) [56].

$$
P_{\text {out }}=\frac{\rho_{w} \cdot g \cdot V_{w} \cdot H}{\eta T}=\frac{\rho_{w} \cdot g \cdot Q_{w} \cdot H}{\eta}
$$

Where:

$Q_{w}=$ volumetric flowrate $\left[\mathrm{m}^{3} /\right.$ day $]$

$\rho_{w}=$ water density $\left[\mathrm{kg} / \mathrm{m}^{3}\right]$;

$g=$ acceleration due to gravity $\left[\mathrm{m} / \mathrm{s}^{2}\right]$;

$H=$ pump head $[\mathrm{m}] ; \eta=$ system efficiency.

The volumetric flow rate of water is therefore evaluated using Equation (27).

$$
\boldsymbol{Q}_{w}=\frac{\eta \cdot \boldsymbol{P}_{\mathrm{out}}}{\rho_{w} \cdot \boldsymbol{g} \cdot \boldsymbol{H}}
$$

When taking into account the efficiency of the pump $\left(\eta_{P U M P}=62 \%\right.$ for the submersible electric pump model $)$ the water pumping capacity rate $\left(F_{w}\right)$ can be expressed as Equation (28).

$$
F_{w}=367 \times \eta_{P U M P} \cdot P_{o u t}
$$

\subsection{Costs analysis}

In this work, the adopted method to evaluate the costs of energy (COE) and costs of water (COW) produced is the present value of costs (PVC) of energy produced per year using Equation (29) [57].

$P V C=I+C_{\text {om }}\left(\frac{1+i}{r-i}\right) \times\left(1-\left(\frac{1+i}{1+r}\right)^{n}\right)-S\left(\frac{1+i}{1+r}\right)^{n}$

Where the following assumptions are made to estimate the cost of energy produced by the considered WT:

- $\boldsymbol{I}$ is the investment cost, which includes the WT price in addition to $20 \%$ for civil works and other connections;

- Average specific WT cost per $\mathrm{kW}$ is USD 1175, for WT rated power between 20 and $200 \mathrm{~kW}$ [53]

- $\boldsymbol{n}$ is the useful lifetime of WT in years (20 yrs); $\boldsymbol{i}_{\boldsymbol{o}}$ is the nominal interest rate $(16 \%)$;

$-\boldsymbol{S}$ is the scrap value (10\% of the WT price); $\boldsymbol{i}$ is the inflation rate $(3.6 \%)$;

- $\boldsymbol{C}_{\boldsymbol{o m}}$ is the operation and maintenance costs ( $7.5 \%$ of the investment cost). [58]:

The discount rate $(\boldsymbol{r})$ is determined using Equation (30)

$$
\boldsymbol{r}=\frac{\boldsymbol{i}_{0}-\boldsymbol{i}}{1+\boldsymbol{i}}
$$

The Wind availability (A) is determined using Weibull CDF of wind speeds at which WT produce energy. The total energy output $\left(E_{W T}\right)$ over the WT lifetime (in kilowatt-hour) is computed as Equation (31).

$$
E_{W}=8760 \times A \times n \times P_{R} \times C_{f}
$$

The cost of energy (COE) per unit $k W h$ using the PVC method can be estimated using Equation (32).

$$
C O E=\frac{P V C}{E_{W}}
$$

The annual volume of water $V_{w}\left(\mathrm{~m}^{3} /\right.$ year $)$ produced by the WT is determined from Equation (33).

$$
V_{w}=\frac{\eta \cdot E_{w}}{n \cdot \rho_{w} \cdot g \cdot H}
$$

The cost of water $(C O W)$ per unit $\mathrm{m}^{3}$ using the PVC method can be estimated using Equation (34).

$$
C O W=\frac{P V C}{n \cdot V_{w}}
$$

\section{Results and discussion}

\subsection{Measured vs satellite data}

Average monthly Weibull CDF values helped to perform the statistical comparison between measured and satellitederived data. Table 4 shows statistical indicators for the accuracy of satellite-derived wind speed for the site of Garoua, which is the only site with measured ground level data. With the exception of May, June and July, satellitederived values are slightly overestimated $(\mathrm{MBE}>0)$ for the rest of the year. The yearly average MBE value of 0.021 indicates a slight overestimation of satellite-derived data. MBE values are in all cases close to zero, which demonstrate a match between locally measured and long-term satellite-derived data. RMSE values range between 0.142 in February and 0.002 in May. These values, close to zero, show successful forecasts. RRMSE values, from April to November, are less than 10\%, denoting an excellent accuracy of satellite-derived data. RRMSE values for January, February, March and December are good, with values ranging from $11.4 \%$ to $15.5 \%$. Overall, the accuracy of satellite-derived data for yearly average is excellent, with a RRMSE value of $6.1 \%$. $R^{2}$ values vary from 0.847 in May to 0.696 in December. $R^{2}$ value of the yearly average is 0.809 . $R^{2}$ values are generally higher and represents a better fit using satellite-derived data. IOA values range between 0.993 and 1.000 and this implies efficiency in using satellite-derived data. Therefore, 
Table 4. Statistical indicators for the accuracy of satellite-derived wind speed for Garoua.

\begin{tabular}{llllll}
\hline Period & MBE & RMSE & RRMSE & $\mathbf{R}^{2}$ & IOA \\
\hline Jan & 0.053 & 0.133 & $14.6 \%$ & 0.759 & 0.993 \\
Feb & 0.058 & 0.142 & $15.5 \%$ & 0.757 & 0.993 \\
Mar & 0.043 & 0.103 & $11.4 \%$ & 0.805 & 0.995 \\
Apr & 0.012 & 0.029 & $3.2 \%$ & 0.841 & 0.999 \\
May & -0.001 & 0.002 & $0.2 \%$ & 0.847 & 1.000 \\
Jun & -0.003 & 0.009 & $1.0 \%$ & 0.848 & 1.000 \\
Jul & -0.001 & 0.004 & $0.4 \%$ & 0.843 & 1.000 \\
Aug & 0.007 & 0.021 & $2.3 \%$ & 0.813 & 0.999 \\
Sep & 0.003 & 0.008 & $0.9 \%$ & 0.792 & 1.000 \\
Oct & 0.004 & 0.011 & $1.2 \%$ & 0.789 & 1.000 \\
Nov & 0.026 & 0.077 & $8.3 \%$ & 0.745 & 0.996 \\
Dec & 0.051 & 0.139 & $15.0 \%$ & 0.696 & 0.993 \\
Yearly average & 0.021 & 0.056 & $6.1 \%$ & 0.809 & 0.998 \\
\hline
\end{tabular}

Table 5. Annual wind characteristics at WT's hub height for the eight sites.

\begin{tabular}{lllllll}
\hline Location & $\mathrm{k}(-)$ & $\boldsymbol{C}(\mathrm{m} / \mathrm{s})$ & $\boldsymbol{V}_{\boldsymbol{m}}(\mathrm{m} / \mathrm{s})$ & $\rho\left(\mathrm{kg} / \mathrm{m}^{3}\right)$ & $\boldsymbol{W}_{\mathrm{PD}}\left(\mathrm{W} / \mathrm{m}^{2}\right)$ & $\boldsymbol{E}_{\mathrm{PD}}\left(\mathrm{kWh} / \mathrm{m}^{2} / \mathrm{day}\right)$ \\
\hline Bashéo & 2.43 & 4.55 & 4.04 & 1.12 & 59.35 & 1.42 \\
Beka & 2.76 & 3.85 & 3.43 & 1.13 & 33.65 & 0.81 \\
Figuil & 2.37 & 4.73 & 4.19 & 1.12 & 67.52 & 1.62 \\
Garoua & 2.63 & 3.89 & 3.46 & 1.13 & 35.55 & 0.85 \\
Pitoa & 2.54 & 4.16 & 3.69 & 1.13 & 44.30 & 1.06 \\
Poli & 3.27 & 3.44 & 3.08 & 1.11 & 21.83 & 0.52 \\
Rey-Bouba & 2.89 & 3.78 & 3.37 & 1.12 & 30.88 & 0.74 \\
Touboro & 3.32 & 3.76 & 3.38 & 1.09 & 28.04 & 0.67 \\
\hline
\end{tabular}

satellite-derived data can accurately represent measured data and when measured ground level data are missing, satellite-derived data can be suitable to assess the potential of wind energy. Similar studies on the use of satellitederived data are found in the literature. Schmidt et al. [23] performed a comparison between in situ measurements of wind speed from Wave Glider (WG) and satellite/ reanalysis products, including the wind speed error per wind speed category, RMSE, bias, and correlation coefficients. Accuracy values are within the same ranges as the present work. Barthelmie and Pryor [21] worked on satellite sampling of offshore wind speeds to represent wind speed distributions. Their study have stressed the difficulties to obtain through in situ methods wind speeds over the oceans. Remmers et al. [22] observed a very strong positive linear relationship between satellite-derived wind speed data and the in situ measurements. Ayompe and Duffy [59] assessed the energy generation potential of photovoltaic systems in Cameroon using satellite-derived solar radiation datasets due to the lack of a reliable network of surface observation stations for collecting weather data in the country. These studies concluded that the accuracy of satellite-derived data varies according to empirical model functions utilized. Besides, the accuracy of satellite-based wind resource is sufficient to provide a reasonable assessment in the initial phase of wind project planning, before higher-accuracy in situ measurements are available.

\subsection{Wind characteristics}

It is observed that the probability of observing higher wind speeds is highest for Figuil. In addition, the probability of observing lower wind speeds is highest for Poli. For each site, the average air density is based on daily average temperature and location values of elevation. Air density values in the North Region vary between 1.10 and $1.13 \mathrm{~kg} / \mathrm{m}^{3}$, while the corresponding elevations are in the range of $291.79-651.63 \mathrm{~m}$. At $10 \mathrm{~m}$ height agl, annual average wind speeds range from $2.24 \mathrm{~m} / \mathrm{s}$ for Poli to $3.16 \mathrm{~m} /$ $\mathrm{s}$ for Figuil, corresponding wind power densities vary from $8.43 \mathrm{~W} / \mathrm{m}^{2}$ for Poli to $28.89 \mathrm{~W} / \mathrm{m}^{2}$ for Figuil. With annual average wind power densities less than $100 \mathrm{~W} / \mathrm{m}^{2}$, the wind resource in the North Region can be ranked as wind power class 1, based on the scheme proposed by Battelle - Pacific Northwest Laboratory (PNL) [60]. Class 1 areas are considered unsuitable for large scale wind power development. It can be further observed that, for each of the eight sites, the peak of the PDFs, which indicates the most frequent wind speed, skews towards the higher values of wind speed. Table 5 proposes statistical Weibull analysis of 
Table 6. Annual average frequency for wind speeds greater or equal to WT cut-in wind speed for different sites.

\begin{tabular}{llllll}
\hline Location & $\mathrm{WT}_{1}$ & $\mathrm{WT}_{2}$ & $\mathrm{WT}_{3}$ & $\mathrm{WT}_{4}$ & $\mathrm{WT}_{5}$ \\
\hline Bashéo & $87.33 \%$ & $76.15 \%$ & $62.59 \%$ & $48.21 \%$ & $34.61 \%$ \\
Beka & $84.20 \%$ & $68.36 \%$ & $49.46 \%$ & $31.21 \%$ & $16.83 \%$ \\
Figuil & $87.95 \%$ & $77.56 \%$ & $64.95 \%$ & $51.41 \%$ & $38.32 \%$ \\
Garoua & $83.44 \%$ & $67.96 \%$ & $49.90 \%$ & $32.52 \%$ & $18.53 \%$ \\
Pitoa & $85.25 \%$ & $71.80 \%$ & $55.76 \%$ & $39.53 \%$ & $25.34 \%$ \\
Poli & $82.91 \%$ & $61.88 \%$ & $36.97 \%$ & $16.44 \%$ & $5.04 \%$ \\
Rey-Bouba & $84.48 \%$ & $67.92 \%$ & $47.87 \%$ & $28.74 \%$ & $14.29 \%$ \\
Touboro & $87.69 \%$ & $71.09 \%$ & $48.90 \%$ & $26.97 \%$ & $11.24 \%$ \\
\hline
\end{tabular}

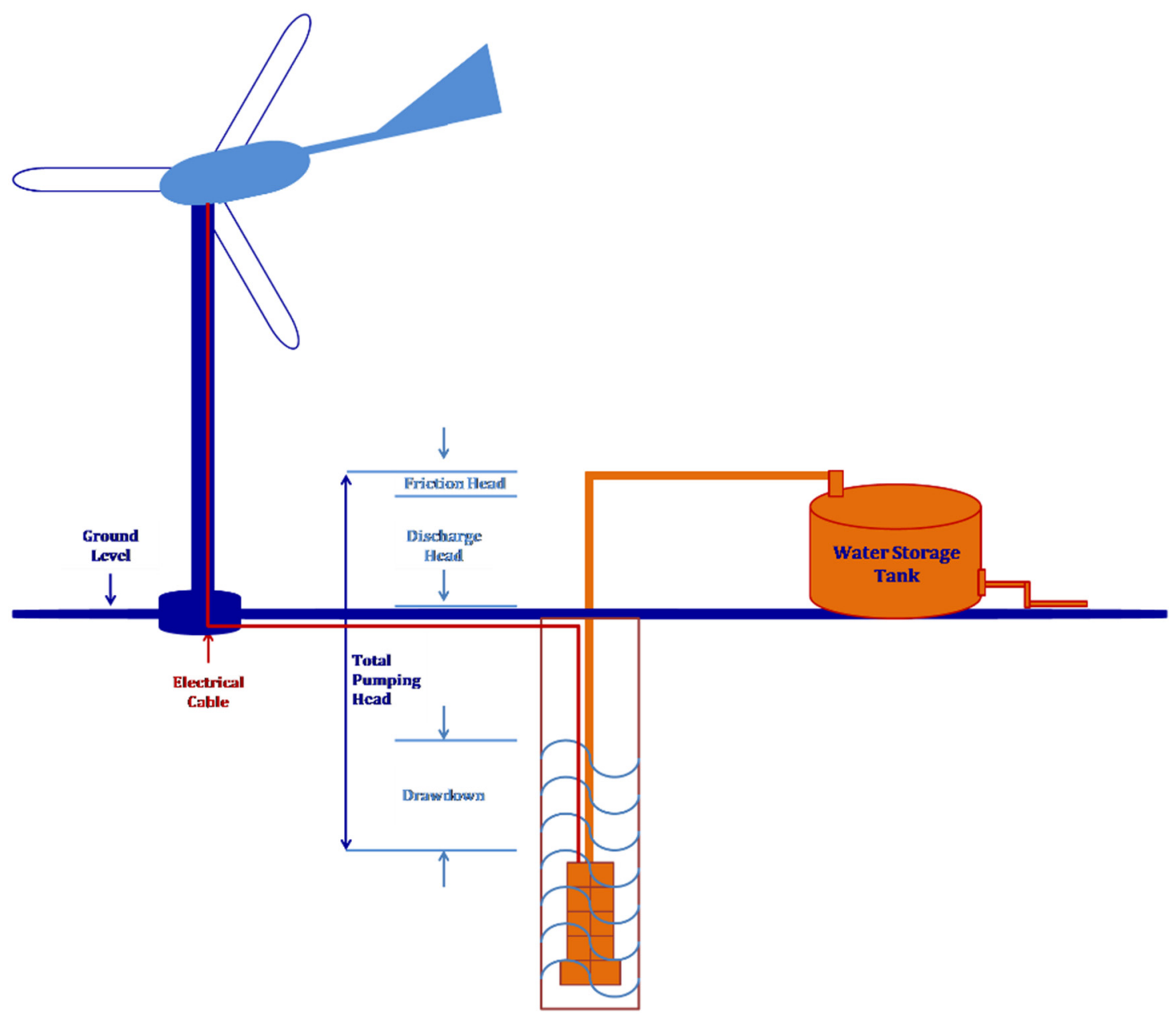

Fig. 5. Typical wind electric pumping systems (WEPS).

wind speed data for $30 \mathrm{~m}$ elevation (tower of WT) for the eight sites. For each site, the average air density was adjusted to reflect the $30 \mathrm{~m}$-hub height tower. Annual average Weibull parameters were extrapolated to the $30 \mathrm{~m}$ height agl, as well as average wind speeds, power densities and energy densities.

Table 6 presents for $\mathrm{WT}_{1}, \mathrm{WT}_{2}, \mathrm{WT}_{3}, \mathrm{WT}_{4}$ and $\mathrm{WT}_{5}$, the annual average frequency for wind speeds greater or equal to WT's cut-in wind speed for each of the eight selectd sites. It's observed that the probability of WT to produce power is the highest using $\mathrm{WT}_{1}$, while this availability is the lowest using $\mathrm{WT}_{5}$.

\subsection{Wind turbine and WEPS}

Figure 5 shows a typical wind electric pumping system. In order to highlight WECS characteristics needed for low wind speed locations, the five WT, with a rated capacity of 


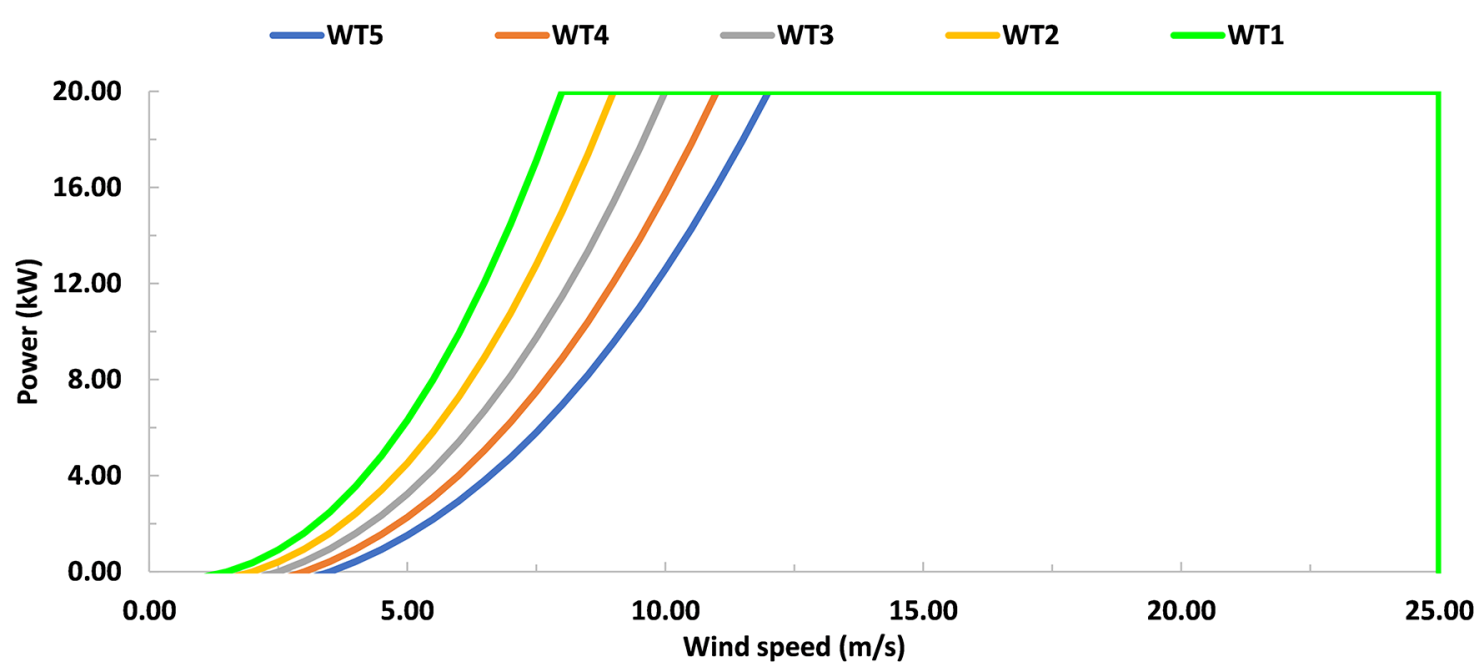

Fig. 6. Power curves of the five selected $20-\mathrm{kW}$ pitch-controlled WT, which combine Figuil wind characteristics.

Table 7. CF and COE using $\mathrm{WT}_{1}, \mathrm{WT}_{2}, \mathrm{WT}_{3}, \mathrm{WT}_{4}$, and $\mathrm{WT}_{5}$, for the eight sites.

\begin{tabular}{|c|c|c|c|c|c|c|c|c|c|c|}
\hline \multirow[t]{2}{*}{ Location } & \multicolumn{2}{|c|}{$\mathrm{WT}_{1}$} & \multicolumn{2}{|c|}{$\mathrm{WT}_{2}$} & \multicolumn{2}{|c|}{$\mathrm{WT}_{3}$} & \multicolumn{2}{|c|}{$\mathrm{WT}_{4}$} & \multicolumn{2}{|c|}{$\mathrm{WT}_{5}$} \\
\hline & $\mathrm{Cf}$ & $\mathrm{COE}$ & $\mathrm{Cf}$ & $\mathrm{COE}$ & $\mathrm{Cf}$ & $\mathrm{COE}$ & $\mathrm{Cf}$ & $\mathrm{COE}$ & $\mathrm{Cf}$ & $\mathrm{COE}$ \\
\hline Bashéo & $23.70 \%$ & 55.28 & $17.03 \%$ & 88.20 & $12.12 \%$ & 150.75 & $8.53 \%$ & 278.22 & $5.90 \%$ & 559.93 \\
\hline Beka & $12.49 \%$ & 108.77 & $8.31 \%$ & 201.50 & $5.44 \%$ & 425.52 & $3.45 \%$ & 1062.82 & $2.09 \%$ & 3248.33 \\
\hline Figuil & $26.52 \%$ & 49.05 & $19.41 \%$ & 76.01 & $14.05 \%$ & 125.39 & $10.06 \%$ & 221.23 & $7.11 \%$ & 420.17 \\
\hline Garoua & $13.98 \%$ & 98.07 & $9.43 \%$ & 178.53 & $6.27 \%$ & 365.88 & $4.05 \%$ & 868.50 & $2.52 \%$ & 2450.37 \\
\hline Pitoa & $17.77 \%$ & 75.51 & $12.31 \%$ & 129.48 & $8.44 \%$ & 243.20 & $5.68 \%$ & 509.78 & $3.72 \%$ & 1213.99 \\
\hline Poli & $5.96 \%$ & 231.43 & $3.67 \%$ & 503.71 & $2.18 \%$ & 1422.70 & $1.20 \%$ & 5799.08 & $0.60 \%$ & 38066.24 \\
\hline Rey-Bouba & $10.80 \%$ & 125.33 & $7.07 \%$ & 238.32 & $4.54 \%$ & 526.41 & $2.81 \%$ & 1416.48 & $1.65 \%$ & 4856.66 \\
\hline Touboro & $7.84 \%$ & 166.42 & $4.93 \%$ & 326.28 & $3.05 \%$ & 767.44 & $1.80 \%$ & 2356.00 & $0.99 \%$ & 10301.13 \\
\hline
\end{tabular}

$20 \mathrm{~kW}$ and a $30 \mathrm{~m}$ tower hub height, were considered for uniformity in the comparison. These WT are represented by $\mathrm{WT}_{1}, \mathrm{WT}_{2}, \mathrm{WT}_{3}, \mathrm{WT}_{4}$ and $\mathrm{WT}_{5}$, to avoid the use of trade names. Cut-in and rated wind speeds are different for each of the five WT. $\mathrm{WT}_{1}$ has the lowest cut-in and rated wind speeds, while $\mathrm{WT}_{5}$ has the highest cut-in and rated wind speeds as illustrated by Table 3 . Five $20-\mathrm{kW}$ pitchcontrolled WT, whose power curves are illustrated by Figure 6, combine Figuil wind characteristics with WT characteristics. The WECS are equipped with a submersible electric pump model to produce energy from wind and pump water using the produced energy for each of the eight selected sites. For the purpose of this work, a total dynamic head of $50 \mathrm{~m}$ was adopted as the average in the NRoC. Any other pumping head could be used since the volumetric flow rate of water is inversely proportional to pumping head.

\subsection{Cost of energy}

Table 7 provides the values of capacity factors $(\mathrm{CF})$ and costs of energy (COE), using $\mathrm{WT}_{1}, \mathrm{WT}_{2}, \mathrm{WT}_{3}, \mathrm{WT}_{4}$ and $\mathrm{WT}_{5}$, for the eight chosen sites. The site of Figuil shows the best combination of $\mathrm{CF}$ and cost of energy, no matter the WT used, followed by the sites of Bashéo and Pitoa. The site of Poli displays the worst CF and COE. For the site of Figuil, the CF is equal to $26.52 \%$ and the COE is 49.05 $\mathrm{XAF} / \mathrm{kWh}$ using $\mathrm{WT}_{1}$. $\mathrm{WT}_{5}$ shows the worst performance, with $\mathrm{CF}$ equal to $7.11 \%$ and $\mathrm{COE}$ equal to $420.17 \mathrm{XAF}$ / $\mathrm{kWh} . \mathrm{WT}_{5}$ displays the poorest performance amongst WT.

\subsection{Flow rate capacity}

Figure 7 presents annual average flow capacity $\left(\mathrm{m}^{4} / \mathrm{h}\right)$ for $\mathrm{WT}_{1}, \mathrm{WT}_{2}, \mathrm{WT}_{3}, \mathrm{WT}_{4}$ and $\mathrm{WT}_{5}$ for the eight selected sites. Figuil shows the best flow rates capacity, 1076, 695, 421, 239 and $125.6 \mathrm{~m}^{4} / \mathrm{h}$, respectively using $\mathrm{WT}_{1}, \mathrm{WT}_{2}$, $\mathrm{WT}_{3}, \mathrm{WT}_{4}$ and $\mathrm{WT}_{5}$. Poli displays the worst flow rates capacity, 228, 105, 37, 9 and $1.4 \mathrm{~m}^{4} / \mathrm{h}$. For the site of Figuil, the annual average flow capacity are $613.76,412.67,233.55$ and $191.28 \mathrm{~m}^{4} / \mathrm{h}$, using $\mathrm{WT}_{1}, \mathrm{WT}_{2}, \mathrm{WT}_{3}, \mathrm{WT}_{4}$ and $\mathrm{WT}_{5}$, in that order. $\mathrm{WT}_{5}$ displays the poorest performance amongst WT.

\subsection{Cost of water}

Table 8 displays the costs of water $(\mathrm{COW})$ and flow rate $\left(\mathrm{m}^{3} /\right.$ day $)$, using $\mathrm{WT}_{1}, \mathrm{WT}_{2}, \mathrm{WT}_{3}, \mathrm{WT}_{4}$ and $\mathrm{WT}_{5}$, for the selected sites. It is observed that Figuil presents the best 


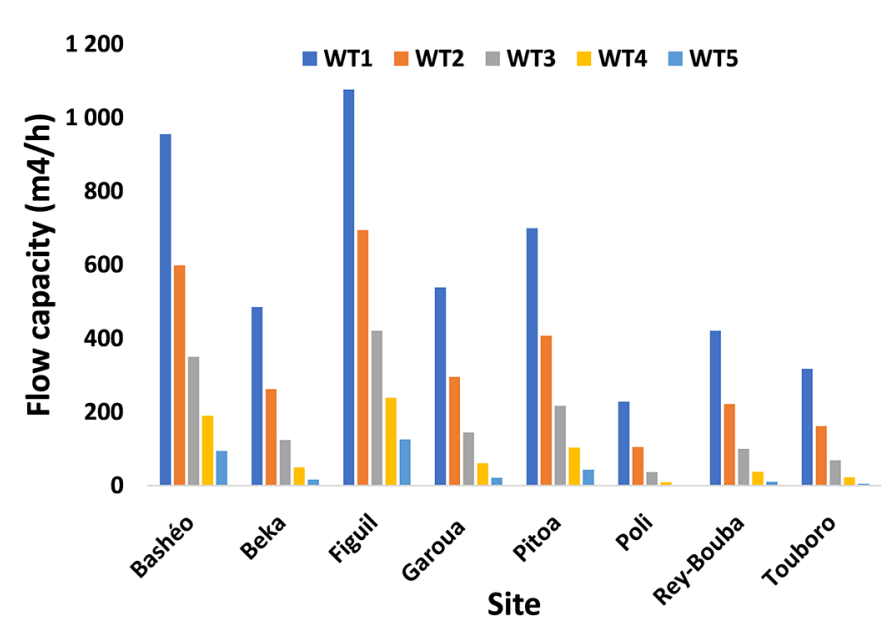

Fig. 7. Annual average flow capacity $\left(\mathrm{m}^{4} / \mathrm{h}\right)$ for $\mathrm{WT}_{1}, \mathrm{WT}_{2}$, $\mathrm{WT}_{3}, \mathrm{WT}_{4}$ and $\mathrm{WT}_{5}$ for the selected sites of the North Region.

combination of COW and flow rate energy, while Poli shows the worst values, independently of WT used. For a total dynamic head of $50 \mathrm{~m}$, the COW for Figuil are 4.01, $9.63,26.20,81.57$ and $294.23 \mathrm{XAF} / \mathrm{m}^{3}$, respectively using $\mathrm{WT}_{1}, \mathrm{WT}_{2}, \mathrm{WT}_{3}, \mathrm{WT}_{4}$ and $\mathrm{WT}_{5}$, while corresponding values of flow rate energy are 1515, 631,232, 74 and $21 \mathrm{~m}^{3}$ / day. $\mathrm{WT}_{5}$, in all cases, shows the poorest performance.

\section{Conclusion}

The economic assessment of wind energy conversions systems, for electric water pumping systems in the NRoC, has been explored, using measured and satellite-derived wind data. The accuracy of satellite-derived wind speeds data was assessed using MBE, RMSE, RRMSE, $\mathrm{R}^{2}$ and IOA indicators. Satellite-based wind resources provided a reasonable accuracy and were deemed a viable alternative to missing site-specific data from ground stations in Bashéo, Beka, Figuil, Pitoa, Poli, Rey-Bouba and Touboro. The energy pattern factor method (EPF) modeled wind speeds characteristics for the assessment of wind energy potential at desired turbines heights in the selected locations. Five 20-kW pitch-controlled WT of $30 \mathrm{~m}$ hub height, assessed the power output and energy produced. The assessment of the wind resource at $10 \mathrm{~m}$ height agl showed average annual power densities in the range of $8.43-28.89 \mathrm{~W} / \mathrm{m}^{2}$. At $10 \mathrm{~m}$ height agl, this wind potential suggests that the NRoC falls under class 1 using the scheme proposed by Battelle-Pacific Northwest Laboratory (PNL). Therefore, the wind resource is deemed unsuitable for large scale WT applications. Hence, the need to use low wind speed WT such as $\mathrm{WT}_{1}$ for electric water pumping applications. Based on its higher performance in comparison to the four other WT, $\mathrm{WT}_{1}$, with the lowest cut-in $(1.5 \mathrm{~m} / \mathrm{s})$ and rated $(8.0 \mathrm{~m} / \mathrm{s})$ wind speeds, showed the highest capacity factors, thus the lowest costs of energy and water produced. As a result, cut-in and rated wind speeds have strong impact on the capacity factor, while cut-out wind speed has negligible impact on it. Choosing WT for low wind speeds regime, require to combine

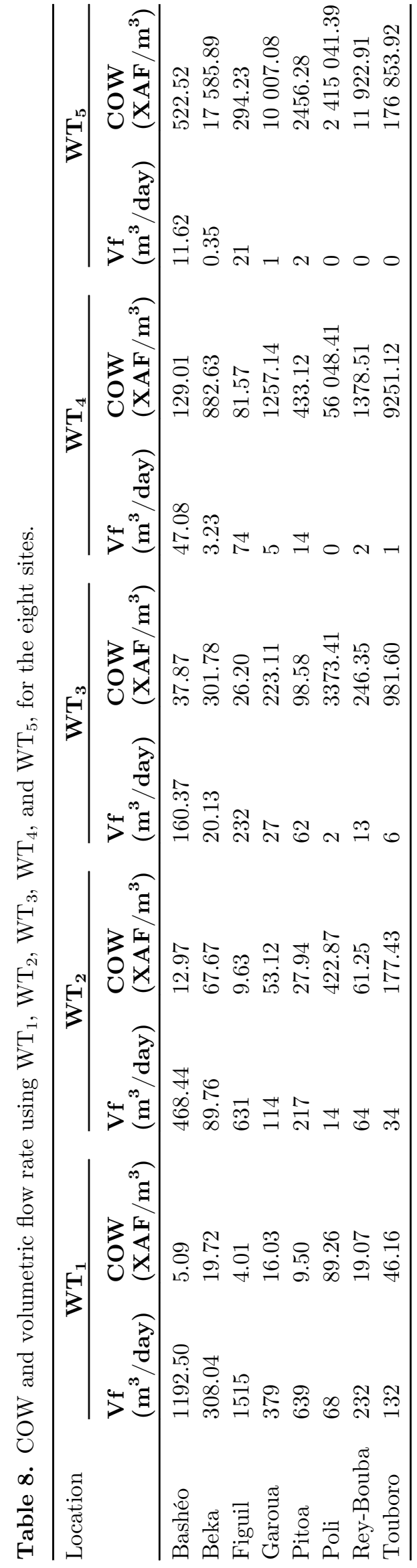


location wind resource and WT characteristics such as cutin and rated wind speeds in order to successfully and affordably implement the wind technology in the NRoC.

\section{Nomenclature}

\begin{tabular}{|c|c|}
\hline$v_{m}$ & Mean wind speed $[\mathrm{m} / \mathrm{s}]$ \\
\hline $\boldsymbol{k}_{10}$ & Shape parameter at $10 \mathrm{~m}$ height agl [-] \\
\hline$k_{z}$ & Shape parameter at $\mathbf{z}$ meters height agl [-] \\
\hline$\sigma$ & $\begin{array}{l}\text { Standard deviation of the mean wind speed } \\
{[\mathrm{m} / \mathrm{s}]}\end{array}$ \\
\hline$n$ & Useful lifetime of WT in years (20 yrs) [year] \\
\hline $\boldsymbol{F}_{\boldsymbol{w}}$ & Water pumping capacity rate $\left[\mathrm{m}^{4} / \mathrm{h}\right]$ \\
\hline$v_{m G}$ & Measured wind speed $[\mathrm{m} / \mathrm{s}]$ \\
\hline$\sigma_{G}$ & $\begin{array}{l}\text { Standard deviation of the mean measured WS } \\
{[\mathrm{m} / \mathrm{s}]}\end{array}$ \\
\hline$v_{m S}$ & Satellite-derived wind speed $[\mathrm{m} / \mathrm{s}]$ \\
\hline$\sigma_{S}$ & $\begin{array}{l}\text { Standard deviation of the mean satellite- } \\
\text { derived WS }[\mathrm{m} / \mathrm{s}]\end{array}$ \\
\hline$f(v)$ & Probability of observing wind speed $v$ \\
\hline$g$ & Acceleration due to gravity $\left[\mathrm{m} / \mathrm{s}^{2}\right]$ \\
\hline $\mathbf{C}$ & Weibull scale parameter $[\mathrm{m} / \mathrm{s}]$ \\
\hline$k$ & Weibull shape parameter $[-]$ \\
\hline $\boldsymbol{E}_{p f}$ & Energy pattern factor $[-]$ \\
\hline$M B E$ & Mean Bias Error [-] \\
\hline$R R M S E$ & Relative root mean square error [\%] \\
\hline$R^{2}$ & Coefficient of determination $[-]$ \\
\hline$G r_{i}$ & $i^{\text {th }} \mathrm{CFD}$ of ground (measured) wind speeds \\
\hline Sat $_{i}$ & $i^{\text {th }} \mathrm{CFD}$ of satellite-derived wind speeds \\
\hline$C_{o m}$ & Operation and maintenance costs [\%] \\
\hline $\mathbf{N}$ & Number of non-zero wind speed data points \\
\hline$C_{10}$ & Scale parameter at $10 \mathrm{~m}$ height agl $[\mathrm{m} / \mathrm{s}]$ \\
\hline$C_{z}$ & Scale parameter at $\mathbf{z}$ meters height agl $[\mathrm{m} / \mathrm{s}]$ \\
\hline$E_{W T}$ & $\begin{array}{l}\text { Total energy output over the WT lifetime } \\
{[k W h]}\end{array}$ \\
\hline$V_{w}$ & Annual volume of water $\left[\mathrm{m}^{3} /\right.$ year $]$ \\
\hline$v_{i}$ & Wind speed $[\mathrm{m} / \mathrm{s}]$ \\
\hline$N$ & Number of wind speed data \\
\hline$v$ & Wind speed $[\mathrm{m} / \mathrm{s}]$ \\
\hline$n$ & Power law exponent $[-]$ \\
\hline$v_{c}$ & Cut-in wind speed $[\mathrm{m} / \mathrm{s}]$ \\
\hline$v_{R}$ & Rated wind speed $[\mathrm{m} / \mathrm{s}]$ \\
\hline$v_{F}$ & Cut-off wind speed $[\mathrm{m} / \mathrm{s}]$ \\
\hline$P_{e R}$ & Rated electrical power $[k W]$ \\
\hline$P_{e, a v e}$ & Average power output $[k W]$ \\
\hline$Q_{w}$ & Volumetric flow rate $\left(\mathrm{m}^{3} /\right.$ day $)$ \\
\hline$\rho_{w}$ & Water density $\left[\mathrm{kg} / \mathrm{m}^{3}\right]$ \\
\hline$\overline{\mathrm{Sat}}$ & Mean value of $S a t_{i}$ \\
\hline $\boldsymbol{H}$ & Pump head $[\mathrm{m}]$ \\
\hline$\eta$ & System efficiency [-] \\
\hline PVC & Present value of costs $[X A F]$ \\
\hline$\eta_{P U M P}$ & Efficiency of the pump [-] \\
\hline$P_{\text {out }}$ & Net hydraulic power output $[k W]$ \\
\hline$I$ & Investment cost $[X A F]$ \\
\hline$i_{o}$ & Nominal interest rate [\%] \\
\hline$S$ & Scrap value $[\%]$ \\
\hline$I$ & Inflation rate $[\%]$ \\
\hline$r$ & Discount rate $[\%]$ \\
\hline$C O E$ & Cost of energy $[X A F / k W h]$ \\
\hline
\end{tabular}

$\boldsymbol{C} \boldsymbol{O} \boldsymbol{W} \quad$ Cost of water $\left[\mathrm{XAF} / \mathrm{m}^{3}\right]$

$\boldsymbol{I O A}$ Index of Agreement

$\boldsymbol{R} \boldsymbol{M S E} \quad$ Root mean square error [-]
The authors gratefully acknowledge the NASA Langley Research Center (LaRC) POWER Project funded through the NASA Earth Science/Applied Science Program for providing wind and temperature data used in this project.

\section{References}

1. K.O. Odeku, An analysis of renewable energy policy and law promoting socio-economic and sustainable development in rural South Africa, J. Hum. Ecol. 40, 53-62 (2012)

2. U. Lehr, A. Mönnig, R. Missaoui, S. Marrouki, G. Ben Salem, Employment from renewable energy and energy efficiency in Tunisia - new insights, new results, Energy Procedia 93, 223-228 (2016)

3. M.S. Salehudin, D.K. Prasad, P. Osmond, Renewable energy potential for energy efficient resort development in Malaysia, Solar 2011, the 49th AuSES Annual Conference, 2011, no. December, pp. 1-10

4. M.O. Oseni, An analysis of the power sector performance in Nigeria, Renew. Sustain. Energy Rev. 15, 4765-4774 (2011)

5. D.K. Kidmo, K. Deli, B. Bogno, Status of renewable energy in Cameroon, Renew. Energy Environ. Sustain. 6, 1-11 (2021)

6. O.S. Ohunakin, Assessment of wind energy resources for electricity generation using WECS in North-Central region, Nigeria, Renew. Sustain. Energy Rev. 15, 1968-1976 (2011)

7. P.K. Halder, N. Paul, M.U.H. Joardder, M. Sarker, Energy scarcity and potential of renewable energy in Bangladesh, Renew. Sustain. Energy Rev. 51, 1636-1649 (2015)

8. K.S. Elie Bertrand, K. Abraham, M. Lucien, Sustainable energy through wind speed and power density analysis in Ambam, South Region of Cameroon, Front. Energy Res. 8, 1-9 (2020)

9. A. Fashina, M. Mundu, O. Akiyode, L. Abdullah, D. Sanni, L. Ounyesiga, The drivers and barriers of renewable energy applications and development in Uganda: a review, Clean Technol. 1, 9-39 (2018)

10. D.A. Salam, A. Riadh, Wind energy state of the art: present and future technology advancements, Renew. Energy Environ. Sustain. 5, 1-8 (2020)

11. D.K. Kidmo, B. Bogno, K. Deli, D. Goron, Seasonal wind characteristics and prospects of wind energy conversion systems for water production in the far North Region of Cameroon, Smart Grid Renew. Energy 11, 127-164 (2020)

12. IRENA, Global renewables outlook: energy transformation 2050 (Abu Dhabi, 2020). www.irena.org/publications

13. M. Harries, Disseminating wind pumps in rural Kenya meeting rural water needs using locally manufactured wind pumps, Energy Policy 30, 1087-1094 (2002)

14. C. Fant, B. Gunturu, A. Schlosser, Characterizing wind power resource reliability in southern Africa, Appl. Energy 161, 565-573 (2016)

15. J. Kenfack, J. Voufo, P.S. Ngohe Ekam, J.K. Lewetchou, U. Nzotcha, Overcoming local constraints when developing renewable energy systems for the electrification of remote areas in Africa, Renew. Energy Environ. Sustain. 5, 1-10 (2020) 
16. NASA, POWER Single Point Data Access (2021). https:// power.larc.nasa.gov/data-access-viewer/ (accessed March 14, 2021)

17. J.W. White, G. Hoogenboom, P.W. Wilkens, P.W. Stackhouse Jr., J.M. Hoel, Evaluation of satellite-based, modeledderived daily solar radiation data for the continental United States, Cimatol. Water Manag. 103, 1242-1251 (2011)

18. J. Bai, X. Chen, A. Dobermann, H. Yang, K.G. Cassman, F. Zhang, Evaluation of nasa satellite-and model-derived weather data for simulation of maize yield potential in China, Agron. J. 102, 9-16 (2010)

19. J.W. White, G. Hoogenboom, P.W. Stackhouse, J.M. Hoell, Evaluation of NASA satellite- and assimilation modelderived long-term daily temperature data over the continental US, Agric. For. Meteorol. 148, 1574-1584 (2008)

20. C.B. Hasager et al., Remote sensing of environment offshore wind climatology based on synergetic use of Envisat ASAR, ASCAT and QuikSCAT, Remote Sens. Environ. 156, 247-263 (2015)

21. R.J. Barthelmie, S.C. Pryor, Can satellite sampling of offshore wind speeds realistically represent wind speed distributions? J. Appl. Meteorol. 42, 83-94 (2003)

22. T. Remmers, F. Cawkwell, C. Desmond, J. Murphy, E. Politi, The potential of advanced scatterometer (ASCAT) $12.5 \mathrm{~km}$ coastal observations for offshore wind farm site selection in Irish waters, 1-16 (2019)

23. K.M. Schmidt, S. Swaart, C. Reason, S.-A. Nicholson, Evaluation of satellite and reanalysis wind products with in situ wave glider wind observations in the Southern Ocean, J. Atmos. Ocean. Technol. 34, 2551-2568 (2017)

24. NASA, NASA Surface meteorology and Solar Energy: RETScreen Data (2020). https://eosweb.larc.nasa.gov/cgibin/sse/sse (accessed Dec. 07, 2020)

25. D.K. Kidmo, R. Danwe, Y.S. Doka, N. Djongyang, Statistical analysis of wind speed distribution based on six Weibull Methods for wind power evaluation in Garoua, Cameroon, J. Renew. Energies 18, 105-125 (2015)

26. D.K. Kidmo, N. Djongyang, S.Y. Doka, D. Raidandi, Assessment of wind energy potential for small scale water pumping systems in the north region of Cameroon, Int. J. Basic Appl. Sci. 3, 38-46 (2014)

27. S.a. Akdağ, A. Dinler, A new method to estimate Weibull parameters for wind energy applications, Energy Convers. Manag. 50, 1761-1766 (2009)

28. N. Izadyar, H. Chyuan, W.T. Chong, K.Y. Leong, Resource assessment of the renewable energy potential for a remote area: a review, Renew. Sustain. Energy Rev. 62, 908-923 (2016)

29. North Region (Cameroon), From Wikipedia, Free Encycl., 2020. https://en.wikipedia.org/wiki/North\%7B_\%7DRe gion\%7B_\%7D(Cameroon)\%7B\#\%7DClimate (accessed Oct. $10, \overline{20} 20$ )

30. K. Mohammadi et al., Assessing different parameters estimation methods of Weibull distribution to compute wind power density, Energy Convers. Manag. 108, 322-335 (2016)

31. K. Mohammadi, O. Alavi, A. Mostafaeipour, N. Goudarzi, M. Jalilvand, Assessing different parameters estimation methods of Weibull distribution to compute wind power density, Energy Convers. Manag. 108, 322-335 (2016)

32. P.A. Costa Rocha, R.C. de Sousa, C.F. de Andrade, M.E.V. da Silva, Comparison of seven numerical methods for determining Weibull parameters for wind energy generation in the northeast region of Brazil, Appl. Energy 89, 395-400 (2012)
33. B. Safari, J. Gasore, A statistical investigation of wind characteristics and wind energy potential based on the Weibull and Rayleigh models in Rwanda, Renew. Energy 35, 2874-2880 (2010)

34. P.A. Costa Rocha, R.C. de Sousa, C.F. de Andrade, M.E.V. da Silva, Comparison of seven numerical methods for determining Weibull parameters for wind energy generation in the northeast region of Brazil, Appl. Energy 89, 395-400 (2012)

35. S.F. Khahro, K. Tabbassum, A.M. Soomro, L. Dong, X. Liao, Evaluation of wind power production prospective and Weibull parameter estimation methods for Babaurband, Sindh Pakistan, Energy Convers. Manag. 78, 956-967 (2014)

36. B. Bailey, S. McDonald, D. Bernadett, M. Markus, K. Elsholz, Wind resource assessment handbook: fundamentals for conducting a successful monitoring program, Music Educ. J. 41, 65 (1997)

37. A. Azad, M. Rasul, T. Yusaf, Statistical diagnosis of the best Weibull methods for wind power assessment for agricultural applications, Energies 7, 3056-3085 (2014)

38. L. Bilir, M. İmir, Y. Devrim, A. Albostan, Seasonal and yearly wind speed distribution and wind power density analysis based on Weibull distribution function Science Direct Seasonal and yearly wind speed distribution and distribution function, Int. J. Hydrogen Energy 40, 1530115310 (2016)

39. I. Fyrippis, P.J. Axaopoulos, G. Panayiotou, Wind energy potential assessment in Naxos Island, Greece, Appl. Energy 87, 577-586 (2010)

40. L. Olatomiwa, S. Mekhilef, O.S. Ohunakin, Hybrid renewable power supply for rural health clinics (RHC) in six geopolitical zones of Nigeria, Sustain. Energy Technol. Assess. 13, 1-12 (2016)

41. J.F. Manwell, J.G. McGowan, A.L. Rogers, Wind energy explained, Theory, Design and Application (BAffins Lane, Chichester, 2002)

42. A. De Meij et al., Wind energy resource mapping of Palestine, Renew. Sustain. Energy Rev. 56, 551-562 (2016)

43. C. Stathopoulos, A. Kaperoni, G. Galanis, G. Kallos, Wind power prediction based on numerical and statistical models, J. Wind Eng. Ind. Aerodyn. 112, 25-38 (2013)

44. T.P. Chang, Wind speed and power density analyses based on mixture Weibull and maximum entropy distributions, Int. J. Appl. Sci. Eng. 8, 39-46 (2010)

45. D.K. Kidmo, R. Danwe, N. Djongyang, S.Y. Doka, Comparison of five numerical methods for estimating Weibull parameters for wind energy applications in the district of Kousseri, Cameroon, Asian J. Nat. Appl. Sci. 3, 72-87 (2014)

46. C. Neme, Statistical analysis of wind speed profile: a case study from Iasi Region, Romania, Int. J. Energy Eng. 3, 261-268 (2013)

47. K. Mohammadi, A. Mostafaeipour, O. Alavi, N. Goudarzi, M. Jalilvand, Assessing different parameters estimation methods of Weibull distribution to compute wind power density, Energy Convers. Manag. 108, 322-335 (2016)

48. T.R.R. Ayodele, A.A.a. Jimoh, J.L.L. Munda, J.T.T. Agee, Wind distribution and capacity factor estimation for wind turbines in the coastal region of South Africa, Energy Convers. Manag. 64, 614-625 (2012)

49. G. Gualtieri, S. Secci, Methods to extrapolate wind resource to the turbine hub height based on power law: a 1-h wind speed vs. Weibull distribution extrapolation comparison, Renew. Energy 43, 183-200 (2012) 
50. A. Mostafaeipour, M. Jadidi, K. Mohammadi, A. Sedaghat, An analysis of wind energy potential and economic evaluation in Zahedan, Iran, Renew. Sustain. Energy Rev. 30, 641-650 (2014)

51. O.S.S. Ohunakin, M.S.S. Adaramola, O.M.M. Oyewola, Wind energy evaluation for electricity generation using WECS in seven selected locations in Nigeria, Appl. Energy 88, 3197-3206 (2011)

52. A.N. Celik, A. Albani, M.Z. Ibrahim, A statistical analysis of wind power density based on the Weibull and Rayleigh models at the southern region of Turkey, Renew. Energy 29, 593-604 (2004)

53. S. Diaf, G. Notton, D. Diaf, Technical and economic assessment of wind farm power generation at Adrar in Southern Algeria, Energy Procedia 42, 53-62 (2013)

54. M.S. Adaramola, O.M. Oyewola, O.S. Ohunakin, O.O. Akinnawonu, Performance evaluation of wind turbines for energy generation in Niger Delta, Nigeria, Sustain. Energy Technol. Assess. 6, 75-85 (2014)
55. E.K. Akpinar, S. Akpinar, An assessment on seasonal analysis of wind energy characteristics and wind turbine characteristics, Energy Convers. Manag. 46, 1848-1867 (2005)

56. S.S. Paul, S.O. Oyedepo, M.S. Adaramola, Economic assessment of water pumping systems using wind energy conversions in the southern part of Nigeria, ENERGY Explor. Exploit. 30, 1-18 (2012)

57. S. Rehman, T.O. Halawani, M. Mohandes, Wind power cost assessment at twenty locations in the kingdom of Saudi Arabia, Renew. Energy 28, 573-583 (2003)

58. S. Mathew, Wind energy: fundamentals, resource analysis and economics, Berlin Heidelberg: Springer-Verlag, 2007

59. L.M. Ayompe, A. Duffy, An assessment of the energy generation potential of photovoltaic systems in Cameroon using satellite-derived solar radiation datasets, Sustain. Energy Technol. Assess. 7, 257-264 (2013)

60. A. Ilinca, E. McCarthy, J.-L. Chaumel, J.-L. Rétiveau, Wind potential assessment of Quebec Province, Renew. Energy 28, $1881-1897(2003)$

Cite this article as: Dieudonné Kaoga Kidmo, Bachirou Bogno, Kodji Deli, Michel Aillerie, Bello Pierre Ngoussandou, Economic assessment of WECS for water pumping systems in the North Region of Cameroon, Renew. Energy Environ. Sustain. 6, 6 (2021) 